\title{
Effect of prebiotic content on functional and physicochemical properties of Lactobacillus casei loaded chitosan-Ca-alginate microparticles
}

\author{
Tanja Petreska Ivanovska ${ }^{1}, K$ ristina Mladenovska ${ }^{1}$, Zoran Kavrakovski ${ }^{1}$, \\ Liljana Bogdanovska ${ }^{1}$, Anita Grozdanov ${ }^{2}$, Emil Popovski $^{3}$, Lidija Petrushevska-Tozi ${ }^{1 *}$ \\ ${ }^{1}$ Faculty of Pharmacy, University "Ss. Cyril and Methodious", Vodnjanska 17, Skopje, Macedonia \\ ${ }^{2}$ Faculty of Technology and Metallurgy, University "Ss Cyril and Methodius", Rudjer Boskovic 16, Skopje, Macedonia \\ ${ }^{3}$ Faculty of Natural Sciences and Mathematics, University "Ss Cyril and Methodius", \\ Arhimedova 5, 1000 Skopje, Macedonia
}

Received: October 2012; Accepted: November 2012

\begin{abstract}
This study aims to evaluate the influence of different concentrations of fructooligosaccharide (FOS) as prebiotic on functional and physicochemical properties of Lactobacillus casei loaded chitosan-Ca-alginate microparticles prepared by spray-drying method, after preparation and 6-month storage at $4{ }^{\circ} \mathrm{C}$. Prebiotic compound positively influenced the viability of $L$. casei during preparation of the microparticles and in storage conditions, while no significant difference of the probiotic viability was observed when different concentrations of FOS in a range of $1.5-5 \% \mathrm{w} / \mathrm{w}$ were applied. Having in regard that non-significant improvement in the functional and physicochemical properties of the microparticles with increased content of the FOS was observed, the concentration of $1.5 \% w / w$ was recommended as an optimal for preparation of synbiotic loaded microparticles.
\end{abstract}

Keywords: prebiotic, fructooligosaccharide, Lactobacillus casei, synbiotic microparticles

\section{Introduction}

The health benefits associated with the consumption of probiotics and/or synbiotics continuously intensify the production of functional foods or pharmaceuticals. For the probiotics to be able to exert their health effects to the humans, they need to be viable in the product and in the gut. The loss of viability can occur on the shelf, prior to consumption, during the processing procedures and conditions (e.g. moisture, oxygen stress, freezing, drying, etc.) and after the consumption, due to the effect of gastric acid or antimicrobial effects of bile salts solutions. Different techniques of microencapsulation have been successfully used to en-

\footnotetext{
*1ito@ff.ukim.edu.mk
}

hance the viability of the probiotics and they are crucial for commercial exploitation because probiotic cells must remain active in the products until consumption (Anal and Singh, 2007; Rokka and Rantamäki, 2010). As any encapsulation method and coating agent beside advantages possesses certain disadvantages, it is interesting to investigate the role of different prebiotics added to the formulation as potential enhancers of the functional and physicochemical properties of the probiotic formulations. According to the literature data, prebiotics may increase survival of probiotics during processing and storage of the product and when applied in the host (Gibson and Roberfroid, 1995). For a compound to be classified as prebiotic ingredient, it must neither be hydrolyzed nor absorbed in the upper part of the gastrointestinal tract and be a selective substrate for beneficial bacteria in the colon and alter the colonic microflo- 
ra toward a healthier composition (Schrezenmeir and de Vrese, 2001). Ultimately, it is the ability of the probiotics to metabolize prebiotics and remain viable, accompanied with the production of lactic, acetic and other short chain organic acids that may be antagonistic to the pathogenic competitors in the intestine (Roberforid, 2001).

For FOSs there are in vivo data that confirm fulfillment of the criteria for successful prebiotic (Gibson et al., 2004). Short-chain FOSs measurably raised fecal counts of bifidobacteria in healthy humans at reasonable dose regimen of 2.5-5 g/day within 7 days of administration (Bouhnik et al., 2004), while Kapiki et al. (2007) observed significantly higher number of bifidobacteria in the lower intestine of the infants fed with FOSs. Kunová et al. (2011) have recently reported the ability of lactobacilli strains both of commercial and human origin to utilize the most commonly used prebiotic oligosaccharides with the best growth on inulin followed by lactulose and raffinose. The stabilizing effects of prebiotics in probiotic products during freezedrying, spray-drying and storage have been also reported (Corcoran et al., 2004; Desmond et al., 2005; Schwab et al., 2007).

Strains of $L$. casei reportedly utilized FOS to produce lactic and acetic acid (Liong and Shah, 2005b) that may have beneficial effects on human glucose and lipid metabolism. Acetate can reduce the concentration of the serum fatty acids, in this way decreasing glucose utilization by the tissues and inducing insulin resistance (Rizkalla et al., 2000; de Santa Olalla et al., 2009). In addition, FOS has favorable safety profile and it ingestion may be accompanied with few adverse effects (flatulence, cramping, diarrhea), usually minor in nature (Chow, 2002).

Chemical composition, bond types and degree of purity of the prebiotic may affect the synbiotic relationship with the probiotic. Besides generally accepted claim that prebiotics in wide concentration range improve probiotic properties, when one probiotic strain is co-encapsulated with the prebiotic compound, the interaction between them has to be characterized. In this study, the influence of FOS concentration applied on the viability of $L$. casei during microencapsulation and in storage conditions at $4^{\circ} \mathrm{C}$ for 6 months and the physicochemical properties of the microparticles was evaluated.

\section{Materials and methods}

\section{Materials}

Freeze-dried probiotic culture of Lactobacillus casei01 was purchased from Chr. Hansen, Denmark. Prebiotic FOS was supplied from Sigma-Aldrich, USA. Sodium alginate (Protanal LF 10/60 LS, fG 35-45\%), which was kindly donated by IMCD, FMC BioPolymer (USA), was used as an encapsulating agent. For additional coating of spraydried microparticles, chitosan with deacetylation degree $\geq$ $85 \%$ and low viscosity 342 (viscosity of $1 \% w / w$ solution in acetic acid 20-100 mPa s, $\mathrm{M}_{\mathrm{w}} 150 \mathrm{kDa}$ ) (Chitine, France) was used, while for cross-linking procedure, $\mathrm{CaCl}_{2}$ (Merck, Germany). The Man Rogosa Sharpe (MRS) broth, MRS agar and peptone water were purchased from Merck, Germany. All the reagents were of analytical grade.

\section{Microencapsulation of Lactobacillus casei}

The method applied to microencapsulate $L$. case $i$ was described in details in previous study (Petreska Ivanovska et al., 2012). Aqueous dispersion of alginate and $L$. casei with a cell load $c a .12 \log$ cfu/g was spray-dried (nozzle diameter $0.7 \mathrm{~mm}$, aspirator pressure $90 \%$, atomizer pressure $600 \mathrm{Nlh}^{-1}$, flow rate $6 \mathrm{ml} / \mathrm{min}$, inlet temperature $120^{\circ} \mathrm{C}$ and outlet temperature $60^{\circ} \mathrm{C}$ ) (Büchi Mini Spray Dryer B-290, Switzerland) to obtain microparticles, which were subsequently cross-linked and coated in solution of $\mathrm{CaCl}_{2}$ and chitosan in $1 \% w / w$ acetic acid. Prepared microparticles were cured for $3 \mathrm{~h}$, separated by centrifugation at $1500 \mathrm{xg}$ for $10 \mathrm{~min}$, and freeze-dried at $0.070 \mathrm{mbar}$ and $-50{ }^{\circ} \mathrm{C}$ for 24 h (FreeZone Freeze Dry System, Labconco, USA).

In order to investigate the optimal content of FOS in the microparticles, the L. casei-alginate dispersion was supplied with the prebiotic at concentrations of 1.5, 3 and 5\% $w / w$ prior to spray-drying. Further, to analyze the influence of the high temperature associated spray-drying process on the prebiotic activity, two series of microparticles containing the lowest concentration of FOS $(1.5 \% \mathrm{w} / \mathrm{w})$ were prepared. In the first, FOS was added during the coating of the microparticles into solution of chitosan and $\mathrm{CaCl}_{2}$ in $1 \%$ $v / v$ acetic acid and in the second prior to freeze-drying.

\section{Viability assay of encapsulated L. casei}

Viability of encapsulated and co-encapsulated $L$. $c a$ sei during preparation of the microparticles and in storage conditions was determined using plate-count method. The prepared microparticles in the predetermined time intervals were dispersed in phosphate buffer solution $(\mathrm{pH}$ 6.9) until complete release of the probiotic cells at room temperature (Petreska Ivanovska et al., 2012). Then, the suspension was serially diluted in $0.1 \%$ sterile peptone solution and appropriate aliquot was plated in triplicate on selective MRS agar and incubated at $37^{\circ} \mathrm{C}$ under aerobic conditions for $72 \mathrm{~h}$. Afterwards, L. casei was enumerated and the average of the results was expressed as colony-forming units per gram of sample $(\mathrm{cfu} / \mathrm{g})$.

\section{Physicochemical characterization of the L. casei loaded microparticles}

Following physicochemical properties of the $L$. $\mathrm{Ca}$ sei loaded chitosan-Ca-alginate microparticles were determined: particle size distribution, Ca-content, and zetapotential. Particle size measurements were performed immediately after sample preparation. Namely, $50 \mathrm{mg}$ of microparticles of each individual series were dispersed in 5 
$\mathrm{ml}$ deionized water, sonicated for $10 \mathrm{~min}$ in ultrasound bath and then passed through a Mastersizer Hydro 2000G (Malvern Instruments Ltd., UK). Samples were added to circulating filtered water until laser obscuration exceeded $10 \%$. The mean particle size of the microparticles was expressed as $d_{50}$. The zeta-potential of the suspended microparticles previously sonicated for $10 \mathrm{~min}$ in ultrasound bath was determined in $0.1 \mathrm{mM}$ phosphate buffer $(\mathrm{pH} 6.8)$ by dynamic light scattering (Zeta-sizer Nano ZS, Malvern Instruments Ltd., UK). For the calcium content measurement, the microparticles were firstly degraded in concentrated $\mathrm{HNO}_{3}$ by boiling $(2.5 \mathrm{mg} / \mathrm{ml})$ (Mladenovska et al., 2007a; Petreska Ivanovska et al., 2012). The calcium content was determined by atomic emission spectroscopy-inductively coupled plasma (AES-ICP, Varian, USA). All measurements for particle size, zeta potential and Ca-content determination were repeated in triplicate for each formulation and results are reported as averages.

\section{Results and discussion}

\section{Effect of FOS concentration on viability of encapsulated L. casei}

The strains of the main probiotic genera Lactobacillus and Bifidobacterium are known to resist gastric acid, bile salts and pancreatic enzymes, to adhere to colonic mucosa and readily colonize the intestinal tract (Fioramonti et al., 2003), but studies indicate poor survival under GI conditions (Kailasapathy, 2002) and also when added to food products as bioactive components (De Vos et al., 2010). Besides microencapsulation that enables physical separation of the cells from the surrounding environment, the presence of prebiotics may increase the resistance of the probiotics to these environmental factors and promote the growth and health effects of the probiotics.

The concentration range of FOS applied in this study $(1.5-5 \% w / w)$ was selected on the basis of data indicating that FOS is effective in humans at doses under $5 \mathrm{~g} /$ day. In a study of Rao (2001), administration of $5 \mathrm{~g}$ FOS daily resulted in a $1 \mathrm{log}$ increase of the bifidobacteria counts compared to a sucrose placebo, while Kelly claimed that dose of $1.25 \mathrm{~g} /$ day FOS is minimal to provide the bifidogenic effect (Kelly, 2009). The results of the viability of L. casei during the encapsulation and co-encapsulation with FOS $(1.5-5 \% w / w)$ in different steps of preparation are presented in Fig. 1a.

The illustration obviously indicates that after spraydrying, the best survival rate of $L$. casei was obtained when FOS was added at concentration of $1.5 \% \mathrm{w} / \mathrm{w}$, while nonsignificant difference in viability of $L$. casei co-encapsulated with FOS at 1.5, 3 and 5\% $w / w$ was observed after freeze-drying. However, the viability of $L$. casei co-encapsulated with different concentrations of FOS $(1.5-5 \% w / w)$ was significantly higher compared to $L$. casei encapsulated without FOS. The positive effect of FOS results from its hydrocolloid properties (Desai et al., 2004), especially im- portant when cell dehydration is caused by high temperature during spray-drying. Freeze-drying as a hyperosmotic process is also detrimental for the cells. However, hydrophilic carbohydrate molecules may be easily accumulated into the cells, thus preventing the denaturation of the cell proteins that is usually associated with the increased content of salts in the medium (Capela et al., 2006). The formation of hydrogen bonds that ensures stable tertiary structure of the proteins in the absence of water (Leslie et al., 1995 ) is the most likely protective mechanism of the cells by oligosaccharides.
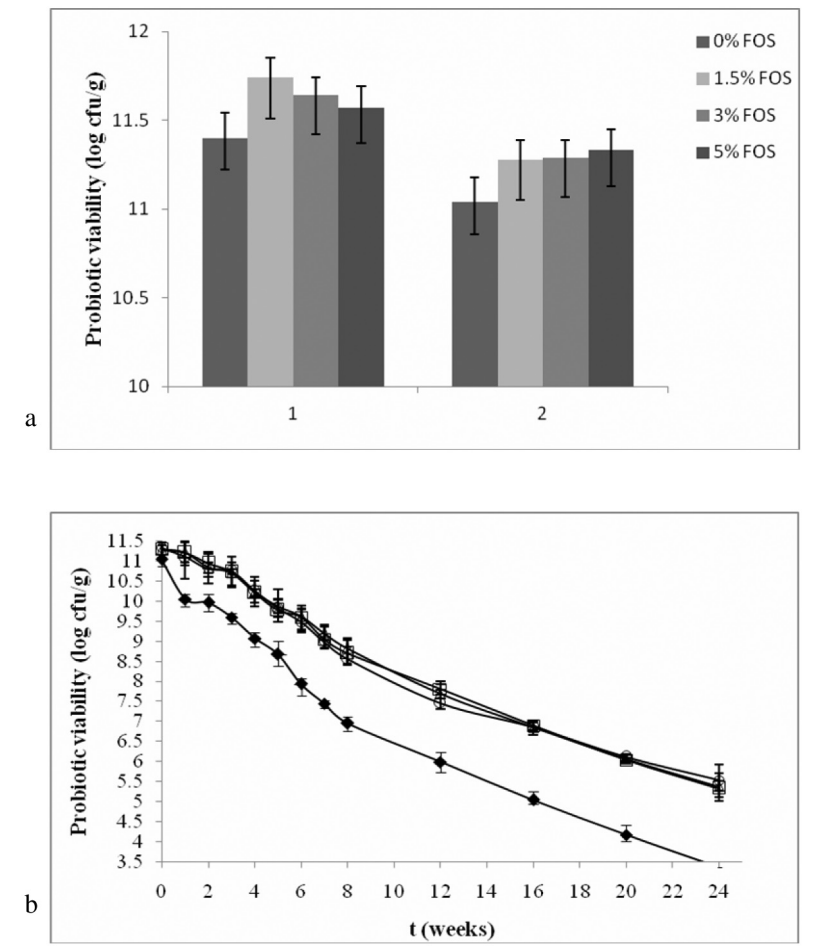

Fig. 1. Viability of Lactobacillus casei: a) during preparation: 1 - after spray-drying; 2 - after freezedrying (viability of the initial suspension was $12.2 \pm 0.46 \log \mathrm{cfu} / \mathrm{g}$ ) and b) during 6-month cold storage of the chitosan-Ca-alginate microparticles: without FOS $(\bullet) ; 1.5 \%(w / w)$ FOS supplied before spray-drying $(\square) ; 3 \%(w / w)$ FOS supplied before spray-drying $(\Delta)$ and 5\% $(w / w)$ FOS supplied before spray-drying $(0)$.

The slight improvement of the probiotic viability is due to the lower stability of FOS under conditions of low $\mathrm{pH}$ and high temperatures, especially when two factors are combined (Huebner et al., 2008; Charalampopoulos and Rastall, 2012). FOS derived from chicory root inulin was found as the most acid-sensitive component $(\mathrm{pH} 2.0$ and 3.0) among wheat bran-derived arabinoxylooligosaccharides and xylooligosasccharides (Courtin et al., 2009), while degradation occurs at processing temperature (60- 
$100{ }^{\circ} \mathrm{C}$ ) and $\mathrm{pH}(2.7-3.3)$ (Matusek et al., 2009). With a view to the $\mathrm{pH}$ of our suspension subjected to spray-drying (5.8-6) and associated high temperature (inlet and outlet temperature of $120^{\circ} \mathrm{C}$ and $60{ }^{\circ} \mathrm{C}$, respectively), partial degradation of the prebiotic FOS is possible.

To overcome eventual hydrolysis by spray-drying, FOS was added during additional coating of the Ca-alginate particles with chitosan and before freeze-drying. The applied modifications have not enhanced the survival rate of the probiotic leading to the conclusion that FOS retains the prebiotic activity under spray-drying conditions. Namely, the reduction in viable cell counts of $L$. casei co-encapsulated with $1.5 \% w / w$ FOS supplied prior to spray-drying, after spray-drying and before freeze-drying was 0.92 logs, 1.39 logs, and $2.14 \operatorname{logs}$ of the initial viability of $12.2 \pm 0.46 \mathrm{log}$ $\mathrm{cfu} / \mathrm{g}$, respectively. Concerning this, Gardiner et al. (2000) and Desmond et al. (2001) claimed that other factors as bacterial strain and species, inoculum type, medium, preadaptation of the culture, are responsible for the viability of the probiotic bacteria subjected to spray-drying, apart from the drying conditions and protective agents.

\section{Effect of FOS concentration on viability of encapsulated L. casei during storage}

Analysis of the relationship probiotic-prebiotic and the role of the prebiotic in the synbiosis may help in the development of new nutraceuticals with prolonged durability. To our knowledge, only few studies evaluated the influence of FOS on the viability of co-encapsulated probiotics in different conditions. Namely, Chen et al. (2005) revealed that co-encapsulation with FOSs and isomaltooligosaccharides enhanced the survival of probiotic strains studied (L. acidophilus, L. casei, B. bifidum, B. longum) during production by extrusion, exposure to acidic and bile salts solutions and 3 months of storage. Ann et al. (2007) concluded that the prebiotic FOS $(1.5 \% v / v)$ positively affected the survival of L. acidophilus ATCC 43121 in the double-coated preparations compared to uncoated and single coated ones produced by hybridization technique. The positive effect of FOS added in probiotic food products was observed after relatively long storage (28 days) in the study of Bozanic et al. (2002) when fermented milks were fortified with high molecular weight FOS such as inulin. Oligofructose enriched reconstituted skim milk showed enhanced survival of six Lactobacillus strains during 4 week storage at 4 ${ }^{\circ} \mathrm{C}$ in comparison to the control (Desai et al., 2004). However, data showing ineffectiveness of inulin and oligofructose as prebiotics have been reported, also. Thus, Drgalic et al. (2005) observed no improvement in the viability of probiotic bacteria in yoghurt containing $1 \% w / v$ inulin. The same was verified by Castro et al. (2009) who used a shortchain oligofructose $(1.4-5 \% \mathrm{w} / \mathrm{v})$ in fermented lactic beverages without significant increase in probiotic viability.

When reviewing our data during 6-month storage of the microparticles at $4{ }^{\circ} \mathrm{C}$, it is obvious that the viability is higher in the microparticles containing FOS (Fig. 1b). In addition, viability assay has shown that the microparticles without FOS retained therapeutic counts of $L$. casei $\left(10^{6}\right.$ $10^{7} \mathrm{cfu} / \mathrm{g}$ ) up to 3 months of cold storage, while the microparticles containing FOS at $1.5 \% w / w$ maintained the therapeutic level of viable cells within 5 months $(6.04 \pm 0.1$ $\log \mathrm{cfu} / \mathrm{g}$ ). The findings are in accordance to the ability of the probiotics to ferment and utilize the prebiotics as energy source (Biedrzycka and Bielecka, 2004). Although, a prebiotic activity of FOS is supposed to be mostly expressed during long-term storage, the results obtained in this study pointed to its most potent effect in the first week of the cold storage. In addition, the strain L. casei-01 survived preferably in the presence of $1.5 \% \mathrm{w} / \mathrm{w}$ FOS, especially in the storage conditions. Increase of the FOS concentration up to $5 \% \mathrm{w} / \mathrm{w}$ did not provide further increase in cell viability (Fig. 1b), thus the concentration above $1.5 \%$ $w / w$ is not economically justified. In the study of Kaplan and Hutkins (2003), FOS was a less usable substrate for the probiotic $L$. paracasei 1195 in the presence of hydrolytic products of the higher oligosaccharides or in the presence of excess glucose, fructose, and sucrose in the assay medium. The divergence of the literature data describing the effect of added prebiotics on probiotic viability can be attributed to a strain-dependant response (Donkor et al., 2007) rather than genera or species confirmed by the time interval need for different prebiotics to stimulate the growth of Lactobacillus and Bifidobacterium species (Huebner et al., 2007).

\section{Effect of FOS on physicochemical properties of the L. Ca- sei loaded microparticles}

In this study, the effect of the concentration of prebiotic FOS on Ca-content of the chitosan-Ca-alginate microparticles was also evaluated. The results obtained indicated that the Ca-content decreased with increasing concentration of FOS in the range of 1.5 to $5 \% w / w$ (Table 1). FTIR studies of the chemical structures and possible interactions among the polymers, alginate and chitosan, cross-linking agent $\mathrm{CaCl}_{2}$, probiotic and prebiotic in the microparticles have confirmed the existence of band $\left(\sim 3360 \mathrm{~cm}^{-1}\right)$ that belongs to the stretching vibrations of the hydroxyl groups of alginate and FOS bonded via hydrogen bonds (data not presented). At higher concentration of FOS, the formation of hydrogen bonds may cause certain conformational changes in the alginate structure, thus less $\mathrm{Ca}$ ions are bond with the carboxylic groups. Considering the similar Ca-content of the synbiotic formulations containing $1.5 \% \mathrm{w} / \mathrm{w}$ FOS supplied before spray-drying, during additional coating and prior to freeze-drying (Table 1), one can conclude that the mechanical stability of the microparticles is not influenced by the preparation step in which FOS would be added to the formulation.

Further, the effect of FOS concentration on the size of $L$. casei loaded microparticles was studied. Micropar- 
Table 1. Physicochemical properties of L. casei loaded chitosan-Ca-alginate microparticles (data points are expressed as means \pm standard deviation of three repeated experiments, $n=3$ )

\begin{tabular}{|c|c|c|c|}
\hline \multirow[b]{2}{*}{ Samples* } & \multicolumn{3}{|c|}{ Physicochemical properties } \\
\hline & $\begin{array}{c}\text { Ca-content } \\
\text { (mg/10 mg particles) }\end{array}$ & $\begin{array}{c}\text { Particle size } \\
\mathrm{d}_{50}(\mu \mathrm{m})\end{array}$ & $\begin{array}{l}\text { Zeta potential } \\
\qquad(\mathrm{mV})\end{array}$ \\
\hline 1 & $0.881 \pm 0.02$ & $9.00 \pm 0.5$ & $44.73 \pm 1.60^{* *}$ \\
\hline 2 & $0.896 \pm 0.02$ & $8.67 \pm 0.4$ & $21.56 \pm 1.10$ \\
\hline 3 & $0.811 \pm 0.03$ & $8.01 \pm 0.4$ & $23.84 \pm 1.22$ \\
\hline 4 & $0.688 \pm 0.02$ & $7.66 \pm 0.2$ & $-33.92 \pm 0.90$ \\
\hline 5 & $0.917 \pm 0.04$ & $8.84 \pm 0.3$ & $-38.14 \pm 1.05$ \\
\hline 6 & $0.880 \pm 0.02$ & $8.52 \pm 0.4$ & $-29.67 \pm 1.31$ \\
\hline
\end{tabular}

*1 - microparticles without FOS;

2 - microparticles prepared with $1.5 \% w / w$ FOS added before spray-drying;

3 - microparticles prepared with $3 \% \mathrm{w} / \mathrm{w}$ added before spray-drying;

4 - microparticles prepared with $5 \% w / w$ FOS added before spray-drying;

5 - microparticles prepared with $1.5 \% w / w$ FOS added during coating / cross-linking procedure;

6 - microparticles prepared with $1.5 \% w / w$ FOS added before freeze-drying.

ticles, smaller in size, are more convenient to be added in food products in order to obtain functional products with favorable sensory and textural properties (O'Riordan et al., 2001). In addition, particles with size less than $10 \mu \mathrm{m}$ are advantageous due to their ability to colonize the lower intestine effectively (Washington et al., 2001) and subsequently to produce positive health effects for the consumer. When comparing the particles containing the same concentration of FOS $(1.5 \% \mathrm{w} / \mathrm{w})$, but added at different preparation steps, non-significant difference in particle size was found. The microparticles without FOS had largest mean diameter, while the microparticles containing 5\% $w / w$ FOS were smallest in size (Table 1). However, the size of the prepared particles supplied with FOS $(1.5,3$ and 5\% $w / w)$ or without FOS is appropriate to provide controlled and targeted release of the probiotic cells in the lower intestine.

Chitosan-Ca-alginate microparticulate system may improve the capacity of the probiotic cells to adhere to the negatively charged intestinal mucosa since the bacterial cells are in general negatively charged (Pelletier et al., 1997). The dominant localization of chitosan in the particle wall that was observed by imaging the chitosan-Ca-alginate particles with FITC-labeled chitosan using confocal laser scanning microscopy (Mladenovska et al., 2007a, b) may produce positively charged microparticles. However, the charge of the prepared particles may be influenced by the concentration of FOS, thus the zeta potential of the particles containing 1.5, 3 and 5\% $w / w$ FOS was determined. The results presented in Table 1 led to the conclusion that favorable alginate-chitosan interaction providing external orientation of the positively charged chitosan was enabled with the presence of FOS up to $3 \% w / w$. The presence of $5 \% w / w$ FOS in the formulation changed the charge to a negative value, probably due to the interaction between the FOS and chitosan. The negative charge of the microparti- cles was also observed when supplemented with $1.5 \% \mathrm{w} / \mathrm{w}$ FOS after spray-drying or prior to freeze-drying. In both ways, the possibility for interaction between chitosan and FOS on the particle surface is increased, thus the positively charged groups of the chitosan became occupied. Having in regard adversely affected surface charge of the particle with the increased content of FOS above 3\% w/w and because no further improvement of the Ca-content and particle size with the increased content of FOS above $1.5 \% \mathrm{w} / \mathrm{w}$ was observed, as an optimal concentration of FOS to be applied in the formulation, $1.5 \% \mathrm{w} / \mathrm{w}$ was chosen.

\section{Conclusion}

The influence of different concentrations of the prebiotic FOS on the viability of chitosan-Ca-alginate loaded $L$. case $i$ and physicochemical properties of the microparticles was studied. The presence of $1.5 \% w / w$ FOS has shown slight improvement in the viability of encapsulated $L$. $c a$ sei during preparation, while the effect was significant during cold storage. However, increased concentration of the prebiotic FOS in the microparticles up to $5 \% w / w$ resulted in no further improvement of the probiotic viability at conditions investigated and physicochemical properties of the microparticles as well. Thus, the probiotic chitosan-Ca-alginate microparticles should be prepared with $1.5 \% \mathrm{w} / \mathrm{w}$ FOS in the dispersion of alginate and L. casei intended for spray-drying, while the synergistic effects of the probiotic L. casei and the prebiotic FOS should be further studied in vitro and in vivo. Further studies are also needed to optimize the concentrations of the polymers and cross-linking agent as factors that may affect the physicochemical properties of the microparticles and viability of $L$. casei under different conditions of the environment. 


\section{Acknowledgments}

This research was financially supported by the Ministry of Education and Science of the Republic of Macedonia (Project No. 13-3583). The authors would like to thank IMCD (UK) for the donation of sodium alginate (Protanal 10/60 LS, FMC BioPolymer).

\section{References}

Anal, A. K., Singh, H., 2007. Recent advances in microencapsulation of probiotics for industrial applications and targeted delivery. Trends Food Sci. Technol. 18, 240-251.

Ann, E.Y., Kim, Y., Oh, S., Imm, J-Y., Park, D-J., Han, K.S., Kim, S.H., 2007. Microencapsulation of Lactobacillus acidophilus ATCC 43121 with prebiotic substrates using a hybridization system. Int. J. Food Sci. Technol. 42, 411-419.

Biedrzycka, E., Bielecka, M., 2004. Prebiotic effectiveness of fructans of different degrees of polymerization. Trends Food Sci. Technol. 15, 170-175.

Bozanic, R., Rogelj, I., Tratnik, L., 2002. Fermentation and storage of probiotic yogurt from goat milk. Dairy 52, 93111.

Bouhnik, Y., Raskine, L., Simoneau, G., Vicaut, E., Neut, C., Flourie, B., Brouns, F., Bournet, F.R., 2004. The capacity of nondigestible carbohydrates to stimulate fecal bifidobacteria in healthy humans:A double-blind, randomized, placebocontrolled, parallel-group, dose response relation study. Am. J. Clin. Nutr. 80, 1658-1664.

Capela, P., Hay, T.K.C., Shah, N.P., 2006. Effect of cryoprotectants, prebiotics and microencapsulation on survival of probiotic organisms in yoghurt and freeze-dried yoghurt. Food Res. Int. 39, 203-211.

Castro, F.P., Cunha, T.M., Ogliari, P.J., Teófilo, R.F., Ferreira, M.M.C., Prudêncio, E.S., 2009. Influence of different content of cheese whey and oligofructose on the properties of fermented lactic beverages: Study using response surface methodology. LWT-Food Sci. Technol. 42, 993-997.

Charalampopoulos, D., Rastall, R.A., 2012. Prebiotics in food. Curr. Opin. Biotechnol. 23, 187-191.

Chen, K.N., Chen, M.J., Liu, J.R., Lin, C.W., Chiu, H.Y., 2005. Optimization of incorporated prebiotics as coating materials for probiotic microencapsulation. J. Food Sci. 70, 260-266.

Chow, J.M., 2002. Probiotics and prebiotics: A brief overview. J. Renal Nutr. 12, 76-86.

Corcoran, B.M., Ross, R.P., Fitzgerald, G.F., Stanton, C., 2004. Comparative survival of probiotic lactobacilli spray-dried in the presence of prebiotic substances. J. Appl. Microbiol. 96, 1024-1039.

Courtin, C.M., Swennen, K., Verjans, P., Delcour, J.A., 2009. Heat and $\mathrm{pH}$ stability of prebiotic arabinoxylooligosaccharides, xylooligosaccharides and fructooligosaccharides. Food Chem. 112, 831-837.

Desai, A.R., Powell, I.B., Shah, N.P., 2004. Survival and activity of probiotics lactobacilli in skim milk containing probiotics. J. Food Sci. 69, FMS557-FMS60.

de Santa Olalla, L.M., Sanchez Muniz, F.J., Vaquero, M.P., 2009. $\mathrm{N}-3$ fatty acids in glucose metabolism and insulin sensitivity. Nutr. Hosp. 24, 113-127.

Desmond, C., Stanton, C., Fitzgerald, G.F., Collins, K., Ross, R.P., 2001. Environmental adaptation of probiotic lactobacilli towards improvement of performance during spray drying. Int. Dairy J. 11, 801-808.

Desmond, C., Corcoran, B.M., Coakley, M., Fitzgerald, G.F., Ross, R.P., Stanton, C., 2005. Development of dairy-based functional foods containing probiotics and prebiotics. Austral. J. Dairy. Technol. 60, 121-126.

De Vos, P., Faas, M.M., Spasojevic, M., Sikkema, J., 2010. Encapsulation for preservation of functionality and targeted delivery of bioactive food components. Int. Dairy J. 20, 292302.

Donkor, O.N., Nilmini, S.L.I., Stolic, P., Vasiljevic, T., Shah, N.P., 2007. Survival and activity of selected probiotic organisms in set-type yoghurt during cold storage. Int. Dairy J. 17, 657665.

Drgalic, I., Tratnik, L., Bozanic, R., 2005. Growth and survival of probiotic bacteria in reconstituted whey. Le Lait: Dairy Sci. Technol. 85, 171-179.

Fioramonti, J., Theodorou, V., Bueno, L., 2003. Probiotics: what are they? What are their effects on gut physiology? Best Pract. Res. Clin. Gastroenterol. 17, 711-724.

Gardiner, G., O'Sulilivan, E., Kelly, J., Auty, M.A.E., Fitzgerald, G.F., Collins, J.K., Ross, R.P., Stanton, C., 2000. Comparative survival rates of human-derived probiotic Lactobacillus paracasei and Lactobacillus salivarius strains during heat treatment spray drying. Appl. Environ. Microbiol. 66, 26052612.

Gibson G.R., Roberfroid M.B., 1995. Dietary modulation of the human colonic microflora: introducing the concept of prebiotics. J. Nutr. 125, 1401-1412.

Gibson, G.R., Probert, H.M., Van Loo, J.A.E., Roberfroid, M.B., 2004. Dietary modulation of the human colonic microbiota: Updating the concept of prebiotics. Nutr. Res. Rev. 17, $257-$ 259.

Huebner, J., Wehling, R.L., Hutkins, R.W., 2007. Functional activity of commercial prebiotics. Int. Dairy J. 17, 770-775.

Huebner, J., Wehling, R.L., Parkhurst, A., Hutkins, R.W., 2008. Effect of processing conditions on the prebiotic activity of commercial prebiotics. Int. Dairy J. 18, 287-293.

Kailasapathy, K., 2002. Microencapsulation of probiotic bacteria: technology and potential application. Curr. Issues Intest. Microbiol. 3, 39-48.

Kapiki, A., Costalos, C., Oikonomidou, C., Triantafyllidou, A., Loukatou, E., Perthrohilou, V., 2007. The effect of a fructooligosaccharide supplemented formula on gut flora of preterm infants. Early Hum. Dev. 83, 335-339.

Kaplan, H., Hutkins, R.W., 2003. Metabolism of fructooligosaccharides by Lactobacillus paracasei 1195 . Appl. Environ. Microbiol. 69, 2217-2222.

Kelly, G., 2009. Inulin-type prebiotics - a review (part 2). Altern. Med. Rev. 14, 36-55.

Kunová, G., Rada, V., Lisová, I., Ročková, Š., Vlková, E., 2011. In vitro fermentability of prebiotic oligosaccharides by lactobacilli. Czech J. Food. Sci. 29, S49-S54.

Leslie, S.B., Israeli, E., Lighthart, B., Crowe, J.H., Crowe, L.M., 1995. Trehalose and sucrose protect both membranes and proteins in intact bacteria during drying. Appl. Environ. Microbiol. 61, 3592-3597.

Liong, M.T. and Shah, N.P. 2005b. Optimization of growth of Lactobacillus casei ASCC 292 and production of organic acids in the presence of fructooligosaccharides and maltodextrin. J. Food Sci. 70, M113-M120.

Matusek, A., Merész, P., Diem Le, T.K., Örsi, F., 2009. Effect of temperature and $\mathrm{pH}$ on the degradation of fructo- 
oligosaccharides. Eur. Food Res. Technol. 228, 355-365.

Mladenovska, K., Raicki, R. S., Janevik, E.I., Ristoski, T., Pavlova, M.J., Kavrakovski Z., Dodov M.G., Goracinova K., 2007a. Colon-specific delivery of 5-aminosalicylic acid from chitosan-Ca-alginate microparticles. Int. J. Pharm. 342 (1-2), 124-136.

Mladenovska, K., Cruaud, O., Richomme, P., Belamie, E., Raicki, R.S., Venier-Julienne, M.-C., Popovski, E., Benoit, J.P., Goracinova, K., 2007b. 5-ASA loaded chitosan-Caalginate microparticles: Preparation and physicochemical characterization. Int. J. Pharm. 345, 59-69.

O’Riordan, K., Andrews, D., Buckle, K., Conway, P., 2001. Evaluation of microencapsulation of a Bifidobacterium strain with starch as an approach to prolonging viability during storage. J. Appl. Microbiol. 91, 1059-1066.

Pelletier, C., Bouley, C., Cayuela, C., Bouttier, S., Bourlioux, P., Bellon-Fontaine, M.-N., 1997. Cell surface characteristics of Lactobacillus casei subsp. casei, Lactobacillus paracasei subsp. paracasei, and Lactobacillus rhamnosus strains. Appl. Environ. Microbiol. 63, 1725-1731.

Petreska Ivanovska, T., Petrusevska-Tozi, L., Dabevska Kostoska, M., Geskovski, N., Grozdanov, A., Stain, C., Stafilov, T., Mladenovska, K, 2012. Microencapsulation of Lactobacillus casei in chitosan-Ca-alginate microparticles using spray- drying method. Maced. J. Chem. Chem. Eng. 31, 115-123.

Rao, V.A., 2001. The prebiotic properties of oligofructose at low intake levels. Nutr. Res. 21, 843-848.

Rizkalla, S.W., Luo, J., Morvarid, K., Chevalier, A., Pacher, N., Gerard, S., 2000. Chronic consumption of fresh but not heated yoghurt improves breath-hydrogen status and shortchain fatty acid profiles: a controlled study in healthy men with or without lactose maldigestion. Am. J. Clin. Nutr. 72, 1474-1470.

Roberfroid, M.B., 2001. Prebiotics: preferential substrates for specific germs? Am. J. Clin. Nutr. 73, 406S-409S.

Rokka, S., Rantamäki, P., 2010. Protecting probiotic bacteria by microencapsulation: challenges for industrial applications. Eur. Food Res. Technol. 231, 1-12.

Schrezenmeir, J., de Vrese, M., 2001. Probiotics, prebiotics, and synbiotics - approaching a definition. Am. J. Clin. Nutr. 73, 361S-364S.

Schwab, C., Vogel, R., Gánzle, M.G., 2007. Influence of oligosaccharides on the viability and membrane properties of Lactobacillus reuteri TMW1.106 during freeze-drying. Cryobiology 55, 108-114.

Washington, N., Washington, C., Wilson, C.G., 2001. Physiological Pharmaceutics - Barriers to Drug Absorption, second ed. Taylor \& Francis, London and New York.

\title{
Резиме
}

\section{Влијание на содржината на пребиотикот врз функционалните и физичко-хемиските својства на цитозан- Са-алгинатните микрочестички со Lactobacillus casei}

\author{
Тања Петреска Ивановска ${ }^{1}$, Кристина Младеновска ${ }^{1}$, Зоран Кавраковски ${ }^{1}$, \\ Лилјана Богдановска ${ }^{1}$, Анита Грозданов ${ }^{2}$, Емил Поповски ${ }^{3}$, \\ Лидија Петрушевска-Този ${ }^{1 *}$
}

\begin{abstract}
IФармацевтски факултет, Универзитет “Св. Кирил и Методиј”, Водњанска 17, Скопје, Македонија ${ }^{2}$ Технолошко-металурики факултет, Универзитет “Св. Кирил и Методиј”, Руѓер Бошковиќ 16, Скопје, Македонија 3Природно-математички факултет, Универзитет “Св. Кирил и Методиј”, Архимедова 5, Скопје, Македонија
\end{abstract}

Клучни зборови: пребиотик, фруктоолигосахарид, Lactobacillus casei, синбиотски микрочестички

Цел на ова истражување е да се оцени влијанието на пребиотикот фруктоолигосахарид врз функционалните и физичкохемиските својства на цитозан-Са-алгинатните микрочестички со Lactobacillus casei во текот на микроинкапсулирањето со примена на методот на распрснување со сушење и при чување на честичките за време од 6 месеци на $4{ }^{\circ} \mathrm{C}$. Притоа, пребиотикот покажа позитивен ефект врз виталноста на $L$. casei, но со зголемување на неговата концентрација во интервалот од $1.5-5 \%$ w/w не беше забележана значајна разлика на виталноста, како во услови на подготовка, така и во услови на чување на честичките. Добиените резултати покажаа дека со зголемување на концентрацијата на фруктоолигосахаридот не доаѓ до значително подобрување на функционалните и физичко-хемиските својства на честичките, од каде произлегува заклучокот дека $1.5 \%$ w/w фруктоолигосахарид претставува оптимална содржина на пребиотикот за подготовка на синбиотските микрочестички. 